\title{
EVALUASI PENERAPAN PENGUNGKAPAN INFORMASI ASET KEUANGAN MENURUT PSAK 60 PADA PT. BANK NEGARA INDONESIA (PERSERO) TBK
}

\author{
Zwingly Juliano Stefanus Pangkey ${ }^{1}$ \\ Lintje Kalangi ${ }^{2}$ \\ Robert Lambey ${ }^{3}$
}

Fakultas Ekonomi dan Bisnis, Jurusan Akuntansi

Universitas Sam Ratulangi Manado

Email: zwinglyp@gmail.com

lintje_kalangi@yahoo.com

robert_lambey@yahoo.com

\begin{abstract}
Financial Assets is one of the factors that really support banking company's business. Statement of Financial Accounting Standards (SFAS) No. 60 about Financial Assets: disclosure head for organize entities to giving disclosure in their financial statements which enable the users to evaluate the significance of financial instruments to the position and financial performance of the entity, characteristic, and risk scope which apeear from financial instruments which the entity's exposed during period and in the end of reporting period, and how the entity managing the risk. The object of this research is PT. Bank Negara Indonesia (Persero) Tbk. with financial statements and notes to the financial statements of December 31, 2014 and 2015 as sample. The data analysis method used in this study is a qualitative method. From the research, the results that can be concluded about the application of financial assets information disclosure at PT. Bank Negara Indonesia (Persero) Tbk. is appropriate with Statement of Financial Accounting Standards (SFAS) No. 48 about financial assets: disclosure but not yet revealing about values related to offsets and about default. Expected in the future PT. Bank Negara Indonesia (Persero) Tbk. could add disclosure about offsetting values and default.
\end{abstract}

Keyword : Bank, Financial Assets, Disclosure, Financial Instrument 


\section{Latar Belakang}

\section{PENDAHULUAN}

Negara Indonesia yang merupakan Negara berkembang memerlukan banyak sokongan dari industri keuangan untuk pembangunan ekonomi Negara. Sektor perbankan adalah sektor utama dalam dunia industri keuangan. Bank memiliki peran vital dalam membangun perekonomian suatu negara, bank harus mampu menjalankan tugasnya dengan baik seperti yang tertulis dalam definisi bank dalam Undang-undang Republik Indonesia No. 10 tahun 1998, bank adalah badan usaha yang menghimpun dana dari masyarakat dalam bentuk simpanan dan menyalurkannya kepada masyarakat dalam bentuk kredit dan atau bentuk-bentuk lainnya dalam rangka meningkatkan taraf hidup rakyat banyak.

Oleh karena perbankan merupakan industri yang sangat penting bagi suatu negara, maka pemerintah memberlakukan aturan atau standar yang ketat bagi perusahaan-perusahaan perbankan yang ada. Dalam membuat laporan keuangannya, perusahaan perbankan harus mengikuti Standar Akuntansi Keuangan yang berlaku supaya memudahkan pengguna untuk membaca dan mendapatkan informasi yang disajikan perusahaan dalam laporan keuangannya tersebut. Standar akuntansi keuangan yang paling berkaitan dengan bank yang merupakan perusahaan di bidang keuangan adalah PSAK 50, yaitu "Instrumen Keuangan: Penyajian", PSAK 55, yaitu "Instrumen Keuangan: Pengakuan dan Pengukuran" serta PSAK 60, yaitu ”Instrumen Keuangan: Pengungkapan”.

PT. Bank Negara Indonesia (persero), Tbk merupakan salah satu Badan Usaha Milik Negara yang sudah go public, bahkan BNI merupakan bank BUMN pertama yang go public setelah BNI mendaftarkan saham mereka pada Bursa Efek Jakarta dan Bursa Efek Surabaya pada tahun 1996. BNI merupakan salah satu dari tiga bank BUMN yang kapitalisasi pasar sahamnya paling besar di Bursa Efek Indonesia saat ini. Sebagai perusahaan yang sudah terdaftar di bursa efek tentunya BNI harus meningkatkan transparansi keuangannya guna membantu investor mengambil keputusan, tentunya laporan keuangan yang diberikan juga harus sesuai dengan standar yang berlaku supaya memudahkan pengguna laporan memahami informasi yang tersedia di dalamnya.

Pada bank-bank yang sudah go public menerapkan PSAK 60 penyesuaian 2014 dalam laporan keuangan adalah sebuah keharusan demi memberikan informasi bagi pembaca laporan keuangan. Pengungkapan mengenai aset keuangan perusahaan sangat penting bagi pengguna laporan keuangan perusahaan. Seperti yang diteliti oleh Bonetti, et al (2012) menunjukan bahwa sebelum berlakunya IFRS 7 [di Indonesia PSAK 60] investor tidak mempunyai cukup informasi untuk membuat pertimbangan mengenai risk and reward dari data yang didapatkan, tetapi IFRS 7 telah menurunkan keraguan investor terhadap keterbukaan informasi perusahaan. Muthupandian (2012) menyatakan bahwa persyaratan pengungkapan dalam IFRS 7 [di Indonesia PSAK 60] mengatur baik penjelasan naratif 'kualitatif' maupun data 'kuantitatif' yang spesifik tentang pengungkapan risiko perusahaan yang muncul akibat instrumen keuangan.

\section{Tujuan Penelitian}

Tujuan dari penelitian ini adalah untuk mengetahui apakah penerapan pengungkapan informasi aset keuangan pada PT. Bank Rakyat Indonesia (persero) Tbk telah sesuai dengan PSAK 60 penyesuaian 2014.

\section{TINJAUAN PUSTAKA}

\section{Akuntansi}

Akuntansi adalah sistem pencatatan dan ringkasan bisnis dan transaksi keuangan serta menganalisis, memverifikasi, dan melaporkan hasilnya (Lam \& Lau, 2012:4). Pontoh (2013:1) menyatakan bahwa pada saat ini akuntansi bukanlah sebuah cabang ilmu ekonomi yang baru, akuntansi telah dikenal secara umum dan merupakan sebuah keahlian yang sangat diperlukan. Akuntansi pada dasarnya akan menghasilkan informasi dari sebuah sistem akuntansi yang ada di 
dalam sebuah entitas atau organisasi bisnis yang disebut dengan informasi akuntansi yang akan dimanfaatkan oleh pengguna seperti masyarakat umum, masyarakat intelektual (termasuk di dalamnya mahasiswa atau peneliti) dan para pengambil keputusan bisnis dalam organisasi.

\section{Akuntansi Keuangan}

Akuntansi keuangan adalah bagian dari akuntansi yang berkaitan dengan penyiapan laporan keuangan untuk pihak luar, seperti pemegang saham, kreditor, pemasok, serta pemerintah. Hal penting dari akuntansi keuangan adalah adanya Standar Akuntansi Keuangan (SAK) yang merupakan aturanaturan yang harus digunakan di dalam pengukuran dan penyajian laporan keuangan untuk kepentingan eksternal.

\section{Tinjauan Tentang Bank}

Bank adalah suatu lembaga keuangan berbentuk badan usaha yang menghimpun dana dari masyarakat dalam bentuk simpanan yang kemudian simpanan tersebut disalurkan kembali kepada masyarakat yang membutuhkan dalam bentuk kredit (Kasmir 2012:12). Bank termasuk perusahaan industri jasa karena produknya hanya memberikan pelayanan jasa kepada masyarakat. Bank adalah salah satu lembaga keuangan yang beroperasi tidak ubahnya sama seperti perusahaan lainnya, yaitu tujuannya mencari keuntungan (Supriyono 2011:1). Bank adalah institusi finansial yang menengahi pembayaran, memberikan pinjaman, dan menerima deposit dari nasabah (Cernohorska : 2015).

\section{PSAK 60}

Ikatan Akuntan Indonesia (2012) Pada 17 desember 2010 DSAK-IAI mengeluarkan IFRS 7 sebagai PSAK 60 Instrumen Keuangan: pengungkapan menggantikan persyaratan pengungkapan dalam PSAK 50, meskipun persyaratan penyajian dalam PSAK 50 tidak berubah. Tujuan PSAK 60 adalah mengatur entitas untuk memberikan pengungkapan dalam laporan keuangannya yang memungkinkan pengguna untuk mengevaluasi sgnifikansi instrumen keuangan bagi posisi dan kinerja keuangan entitas tersebut; disamping sifat dan tingkat risiko yang muncul akibat instrumen keuangan tersebut selama periode berjalan dan pada tanggal pelaporan serta bagaimana entitas tersebut mengelola risiko itu. PSAK 60 mensyaratkan untuk mengungkapkan:

\section{Laporan Posisi Keuangan}

\section{Kategori Aset Keuangan dan Liabilitas Keuangan}

Nilai tercatat dari masing-masing kategori, sebagaimana didefinisikan dalam PSAK 55, harus diungkapkan dalam laporan posisi keuangan atau dalam catatan atas laporan keuangan.

\section{Aset Keuangan atau Liabilitas Keuangan Pada Nilai Wajar Melalui Laba Atau Rugi}

Entitas mengungkapkan metode yang digunakan untuk memenuhi persyaratan, jika entitas meyakini bahwa pengungkapan yang memenuhi persyaratan tidak menyajikan secara jujur perubahan nilai wajar aset keuangan atau liabilitas keuangan yang dapat di atribusikan pada perubahan risiko kredit, alasan-alasan yang menghasilkan kesimpulan tersebut dan faktor-faktor relevan yang dipercayai entitas.

\section{Reklasifikasi}

Jika entitas sudah mereklasifikasi suatu aset keuangan sebagai aset yang diukur (i) pada harga perolehan atau biaya amortisasi, bukan pada nilai wajarnya; atau (ii) pada nilai wajar, bukan pada harga perolehan atau biaya amortisasi, PSAK 60 mensyaratkan bahwa entitas itu mengungkapkan jumlah yang direklasifikasikan ke dalam atau dihapus dari masing-masing kategori serta alasan reklasifikasi tersebut.

\section{Saling Hapus Aset Keuangan Dan Liabilitas Keuangan}

Jika suatu entitas telah mengalihkan aset keuangan dengan suatu cara yang mengakibatkan sebagian atau seluruh aset keuangan itu tidak memenuhi syarat penghapusan dan pengakuan, PSAK 
60 mensyaratkan bahwa entitas itu mengungkapkan sifat aset itu, sifat risiko dan manfaat kepemilikan yang tetap dimiliki entitas itu, nilai tercatat dari aset itu serta liabilitas terkaitnya, nilai tercatat dari aset awal, saldo aset yang tetap diakui oleh entitas itu, serta nilai tercatat dari liabilitas terkaitnya.

\section{Agunan}

Jika ada agunan (collateral) tertentu, PSAK 60 mensyaratkan bahwa entitas itu mengungkapkan nilai tercatat dari aset keuangan yang dijamin dalam liabilitas atau liabilitas kontijensi, termasuk saldo yang telah direklasifikasi serta syarat dan ketentuan penjamin tersebut.

\section{Akun Penyisihan Kerugian Kredit}

Jika aset keuangan mengalami penurunan nilai karena kerugian kredit dan entitas mencatat penurunan nilai dalam pos terpisah (misalnya pos penyisihan digunakan untuk mencatat penurunan nilai individual atau pos serupa yang digunakan untuk mencatat penurunan nilai kolektif atas aset keuangan) daripada secara langsung mengurangi nilai tercatat aset keuangan, maka entitas mengungkapkan suatu rekonsiliasi perubahan pada akun tersebut selama periode untuk setiap kelompok aset keuangan.

\section{Instrumen Keuangan Majemuk dengan Derivatif Melekat}

Jika entitas menerbitkan instrumen yang mengandung komponen liabilitas dan ekuitas (lihat PSAK 50:Instrumen Keuangan: Penyajian paragraf 31) dan instrumen tersebut memiliki beberapa derivatif melekat yang nilainya saling tergantung satu sama lain (seperti callable convertibledebt instrument), maka entitas mengungkapkan keberadaan fitur tersebut.

\section{Gagal Bayar dan Pelanggaran}

Untuk utang pinjaman (loans payable) yang diakui pada tanggal pelaporan, PSAK 60 mensyaratkan mengungkapkan (a) Rincian tentang segala gagal bayar selama periode syarat jumlah pokok pinjaman, bunga, dana tebusan, atau penebusan dari utang pinjaman tersebut. (b) Nilai tercatat dari utang pinjaman dalam gagal bayar pada tanggal pelaporan. (c) Apakah gagal bayar telah dipulihkan, atau syarat utang pinjaman dinegosiasikan ulang, sebelum laporan keuangan disahkan pihak berwenang untuk dikeluarkan.

\section{Laporan Laba Rugi dan Penghasilan Komprehensif Lain}

\section{Pos-Pos Penghasilan, Beban, Keuntungan dan Kerugian}

PSAK 60 mensyaratkan pengungkapkan pos-pos penghasilan (income), beban (expense),keuntungan (gain) atau kerugian (loss) berikut ini pada laporan laba-rugi komprehensif atau dalam laporan perubahan ekuitas, atau dalam catatan atas laporan keuangan.

\section{Pengungkapan Lain}

\section{Kebijakan akuntansi}

Sesuai dengan PSAK 1: Penyajian Laporan Keuangan paragraf 117, entitas mengungkapkan dalam ikhtisar kebijakan akuntansi yang signifikan, dasar pengukuran yang digunakan dalam menyusun laporan keuangan dan kebijakan akuntansi lain yang relevan untuk pemahaman suatu laporan keuangan.

\section{Akuntansi Lindung Nilai}

Entitas mengungkapkan hal-hal berikut secara terpisah untuk setiap jenis lindung nilai yang diuraikan dalam PSAK 55: Instrumen Keuangan: Pengakuan dan Pengukuran (yaitu lindung nilai atas nilai wajar, lindung nilai atas arus kas, dan lindung nilai atas investasi neto pada operasi luar negeri).

\section{Nilai Wajar}

Kecuali yang diuraikan, untuk setiap kelompok aset keuangan dan liabilitas keuangan, entitas mengungkapkan nilai wajar dari kelompok aset dan liabilitas keuangan tersebut dengan cara yang memungkinkan untuk dibandingkan dengan jumlah tercatatnya. 


\section{Pengungkapan Risiko}

PSAK 60 mensyaratkan bahwa suatu entitas mengungkapkan informasi yang memungkinkan pengguna laporan keuangannya untuk mengevaluasi sifat dan tingkat risiko yang muncul akibat instrumen keuangan yang dihadapi entitas tersebut pada tanggal pelaporan. Risiko itu biasanya meliputi, namun tidak berbatas pada, risiko kredit, risiko likuiditas, dan risiko pasar.PSAK 60 secara khusus mensyaratkan pengungkapan baik informasi kulitatif maupun informasi kuantitatif.

\section{Pengungkapan kualitatif}

Untuk setiap jenis risiko yang timbul dari instrumen keuangan, entitas mengungkapkan (a) eksposur risiko dan bagaimana risiko itu timbul. (b) Tujuan, kebijakan, dan proses pengelolaan risiko dan metode yang digunakan untuk mengukur risiko tersebut. (c) Segala perubahan butir (a) dan (b) dari periode sebelumnya.

\section{Pengungkapan Kuantitatif}

Jika data kuantitatif yang diungkapkan pada tanggal pelaporan memperlihatkan risiko yang dihadapi suatu entitas selama periode berjalan, maka entitas tersebut harus mengungkapkan informasi yang representatif. Guna memenuhi persyaratan ini, suatu entitas dapat mengungkapkan jumlah tertinggi, terendah, dan rata-rata resiko yang akan dihadapinya selama periode berjalan. Jenis risiko yang termasuk dalam pengungkapan kuantitatif adalah Risiko kredit, Risiko Likuiditas dan Risiko Pasar.

\section{Penelitian Terdahulu}

Longgorung (2015) dengan judul Pengungkapan Informasi Aset Keuangan Menurut PSAK 60 Pada PT. Bank Rakyat Indonesia (Persero) Tbk. Tujuannya untuk melihat apakah bank BRI dalam mengungkapkan aset keuangan telah sesuai dengan PSAK 60 penyesuaian 2012. Metode yang digunakan adalah deskriptif. Hasil penelitian menunjukkan bank BRI dalam pengungkapan aset keuangannya sudah sesuai dengan PSAK 60 penyesuaian 2012 tetapi manajemen belum menerapkan pengungkapan gagal bayar dan pelanggaran.

Larasati dan Supatmi (2013) dengan judul Pengungkapan Informasi Aset Keuangan dan Impairment-nya di Perbankan menurut PSAK 50 dan 60. Tujuannya Untuk mendeskripsikan tingkat kepatuhan bank-bank Indonesia atas penerapan Standar Akuntansi berdasarkan PSAK 50 dan 60 (revisi 2010). Metode yang digunakan yaitu Penelitian deskriptif dengan menggunakan purposive sampling. Hasil penelitiannya (1) aset keuangan jenis pinjaman yang diberikan, dan piutang, memiliki total aset keuangan paling besar, sedangkan tersedia untuk dijual memiliki penurunan nilai paling besar. (2) Dari tahun 2010-2012, semakin tinggi tingkat kepatuhan perbankan untuk penerapan PSAK 50 dan 60. (3) Semakin banyak jumlah perbankan yang mengungkapkan kebijakan instrumen keuangan yang sangat spesifik.

Emanuela (2012) dengan judul Analisis Penerapan PSAK 50 dan 55 (revisi 2006) Atas Impairment piutang pada Perusahaan Multifinance. Tujuannya untuk melihat penerapan PSAK 50 dan 55 (revisi 2006) dilihat dari pengukuran, pengakuan, penyajian dan pengungkapan penurunan piutang; memberikan gambaran mengenai dampak yang timbul akibat munculnya penurunan piutang hasil dari penerapan PSAK 50 dan 55 (revisi 2006) bagi kinerja keungan perusahaan. Metode yang digunakan adalah analisis komparatif terhadap sampel laporan keuangan perusahaan pembiayaan yang terdaftar di BEI. Hasil penelitian menunjukan penurunan beban cadangan penurunan nilai piutang dari tahun 2009 ke 2010 memberikan dampak pada kenaikan presentase laba bersih suatu perusahaan. Peneliti sebelumnya menyarankan Dewan Standar Akuntansi Keuangan untuk menentukan metode yang harus dipakai untuk menghitung penurunan nilai piutang. 


\section{METODE PENELITIAN}

\section{Jenis Penelitian}

Jenis penelitian ini adalah penelitian kualitatif deskriptif, yaitu analisis yang dilakukan dengan membandingkan antara teori dan penerapannya untuk melihat kesesuaian dan perbedaan antara teori dan praktek. Dalam hal ini, penulis akan membandingkan pengungkapan informasi aset keuangan dalam PSAK 60 (revisi 2014) dengan penerapannya pada laporan keuangan PT. Bank Negara Indonesia (persero), Tbk.

\section{Tempat dan Waktu Penelitian}

Penelitian ini mengambil data penelitian di website resmi PT. Bank Negara Indonesia (Persero) Tbk dan pada website Bursa Efek Indonesia. Penelitian dimulai dari bulan Februari sampai dengan Maret 2016.

\section{Prosedur Penelitian}

Prosedur yang digunakan dalam penelitian ini adalah:

1. Survey Pendahuluan

Langkah awal adalah mengidentifikasi masalah yang akan diangkat dalam penelitian ini.

Kemudian menentukan judul penelitian yang sesuai.

2. Identifikasi Objek

Objek yang akan diteliti dalam penelitian adalah PT. Bank Negara Indonesia (persero), Tbk. yang merupakan salah satu bank BUMN terbesar dan sudah go public. Setelah menentukan objek yang akan digunakan dalam penelitian ini, maka selanjutnya penulis mengidentifikasi gambaran umum perusahaan.

3. Pengumpulan Data

Pengumpulan data yang dilakukan oleh penulis, dengan cara mengakses data berupa laporan keuangan tahunan, yang dapat diakses melalui website Bank BNI (www.bni.co.id), atau juga melalui website Bursa Efek Indonesia (www.idx.co.id)

4. Analisa Data

Setelah memperoleh data yang diperlukan, penulis menganalisa data-data yang ada dan mengolah data-data tersebut sesuai dengan rumusan masalah yang telah ditentukan sebelumnya.

5. Penarikan Kesimpulan

Setelah menganalisa dan mengolah data yang telah diperoleh sebelumnya, penulis kemudian akan menarik kesimpulan sesuai dengan analisa dan olahn data yang telah dilakukan.

\section{Metode Pengumpulan Data}

Metode pengumpulan data dalam penelitian ini adalah studi dokumentasi dan studi kepustakaan. Dokumentasi dilakukan terhadap data yang digunakan yaitu laporan keuangan tahunan PT. Bank Negara Indonesia (Persero), Tbk. Studi kepustakaan dilakukan dengan cara mendapatkan informasi dari teori-teori yang ada dengan cara mempelajari dari buku-buku literature, jurnal, serta bahan-bahan informasi lainnya yang berhubungan dengan masalah yang diteliti oleh penulis..

\section{Metode Analisis Data}

Menurut Sugiyono (2012:3), metode dalam penelitian pada dasarnya merupakan cara ilmiah untuk mendapatkan data dengan tujuan tertentu. Data dan informasi yang dikumpulkan akan dianalisis dengan menggunakan analisis kualitatif deskriptif yaitu untuk mengumpulkan, menyusun, menganalisis data, memperoleh gambaran yang sebenarnya bagaimana PSAK 60 penyesuaian 2014 tentang pengungkapan informasi aset keuangan pada perusahaan untuk kemudian dibandingkan dengan teori yang ada sehingga mampu memberikan informasi yang lengkap bagi pemecahan masalah yang dihadapi. 
Hasil Penelitian

HASIL PENELITIAN DAN PEMBAHASAN

\section{Deskripsi Objek Penelitian}

Didirikan pada tanggal 5 Juli 1946, PT Bank Negara Indonesia (persero) Tbk atau BNI menjadi bank pertama milik negara yang lahir setelah kemerdekaan Indonesia. Sesuai dengan UU No.17 Tahun 1968 sebagai bank umum dengan nama Bank Negara Indonesia 1946, BNI bertugas memperbaiki ekonomi rakyat dan berpartisipasi dalam pembangunan ekonomi nasional. BNI kembali mencatat sejarah dengan menjual saham perdananya kepada masyarakat melalui Bursa Efek Jakarta (BEJ) dan Bursa Efek Surabaya (BES) pada tahun 1996. Dalam sejarah perbankan nasional, BNI menjadi bank negara pertama yang go-public. Bersamaan dengan program divestasi saham pemerintah, BNI menerbitkan saham baru pada tahun 2007 dan 2010 melalui Penawaran Umum Terbatas (right issue) dengan memperluas komposisi kepemilikan saham publik menjadi $40 \%$.

\section{Visi dan Misi PT. Bank Negara Indonesia (persero) Tbk.}

Setiap perusahaan memiliki Visi dan Misi untuk kemajuan perusahaan kearah yang lebih baik. Demikian juga dengan PT. Bank Negara Indonesia (persero) Tbk. Visi dan Misi PT. Bank Negara Indonesia (persero) Tbk :

\section{a. Visi PT. Bank Negara Indonesia (persero) Tbk}

Visi PT. Bank Negara Indonesia adalah: "Menjadi bank yang unggul, terkemuka, dan terdepan dalam layanan dan kinerja". BNI berupaya menjadi Bank yang 'unggul' dalam bidang human capital yang berkualitas, proses bisnis internal yang memberi nilai bagi nasabah melalui improvement dan inovasi melalui produk/jasa yang beragam dan terpadu, serta pengelolaan perbankan berkualitas dengan risiko terukur. 'Terkemuka' adalah menjadi bank pilihan utama dengan kualitas layanan terbaik yang pada akhirnya akan menjadikan BNI 'terdepan' dalam hal kinerja keuangan yang berkualitas dibandingkan peers sehingga memberikan kualitas investasi yang memuaskan bagi pemangku kepentingan.

b. Misi PT. Bank Negara Indonesia (persero), Tbk

Untuk mewujudkan visinya, BNI mempunyai misi sebagai berikut:

i. Memberikan layanan prima dan solusi yang bernilai tambah kepada seluruh nasabah, dan selaku mitra pilihan utama

ii. Meningkatkan nilai investasi yang unggul bagi investor

iii. Menciptakan kondisi terbaik bagi karyawan sebagai tempat kebanggaan untuk berkarya dan berprestasi

iv. Meningkatkan kepedulian dan tanggung jawab terhadap lingkungan dan komunitas

v. Menjadi acuan pelaksanaan kepatuhan dan tata kelola perusahaan yang baik

\section{Kebijakan Akuntansi PT. Bank Negara Indonesia (persero) Tbk}

Laporan Keuangan PT. Bank Negara Indonesia (persero) Tbk tahun 2015 telah diotorisasi oleh direksi pada tanggal 25 Januari 2016. Dasar penyusunan laporan keuangan konsolidasian adalah Standar Akuntansi Keuangan di Indonesia, dan Peraturan Bapepam dan LK No. VIII.G.7 Lampiran Keputusan Ketua Bapepam dan LK No. KEP-347/BL/2012 tanggal 25 Juni 2012 tentang "Pedoman Penyajian dan Pengungkapan Laporan Keuangan Emiten atau Perusahaan Publik". Pada laporan keuangan tahunan perusahaan tahun 2015, PT. Bank Negara Indonesia, (Persero), Tbk telah menerapkan standar akuntansi revisi yang dianggap perusahaan relevan dengan laporan keuangan konsolidasian BNI dan Entitas Anak. Salah satu standar revisi baru yang diterapkan perusahaan adalah PSAK 60 (revisi 2014) yang penerapannya diyakini perusahaan tidak menimbulkan perubahan substansial terhadap kebijakan akuntansi perusahaan dan tidak berdampak signifikan terhadap jumlah yang dilaporkan pada periode berjalan atau periode sebelumnya. 
Evaluasi Penerapan Pengungkapan Informasi Aset Keuangan Menurut PSAK 60 pada PT. Bank Negara Indonesia (persero) Tbk

Tabel 1. Perbandingan Pengungkapan Aset Keuangan berdasarkan PSAK 60 dengan PT BNI Tbk pada Laporan Posisi Keuangan PT. BNI, Tbk

\begin{tabular}{|c|c|c|}
\hline Berdasarkan PSAK 60 & Berdasarkan Bank BNI & Keterangan \\
\hline $\begin{array}{l}\text { Kategori aset keuangan } \\
\text { dan liabilitas keuangan }\end{array}$ & $\begin{array}{l}\text { BNI mengkategorikan aset keuangan dalam } 4 \text {, yaitu (1) aset } \\
\text { keuangan yang diukur pada nilai wajar melalui laporan laba- } \\
\text { rugi, (2) pinjaman yang diberikan dan piutang, (3) Aset } \\
\text { keuangan yang dimiliki hingga jatuh tempo, (4) aset keuangan } \\
\text { tersedia untuk dijual. BNI mengungkapkan nilai tercatat } \\
\text { dalam Catatan Atas Laporan keuangan }\end{array}$ & Sesuai \\
\hline $\begin{array}{l}\text { Aset keuangan atau } \\
\text { liabilitas keuangan yang } \\
\text { diukur pada nilai wajar } \\
\text { melalui laba rugi }\end{array}$ & $\begin{array}{l}\text { Dalam kategori aset keuangan yang diukur pada nilai wajar } \\
\text { BNI, tidak terdapat aset keuangan yang juga merupakan } \\
\text { kategori pinjaman yang diberikan dan piutang }\end{array}$ & Sesuai \\
\hline Reklasifikasi & $\begin{array}{l}\text { BNI mengungkapkan reklasifikasi yang dilakukan dari } \\
\text { kategori tersedia untuk dijual ke kategori dimiliki hingga } \\
\text { jatuh tempo dan juga alasan melakukan reklasifikasi dan } \\
\text { jumlah reklasifikasi }\end{array}$ & Sesuai \\
\hline $\begin{array}{l}\text { Saling hapus aset } \\
\text { keuangan dan liabilitas } \\
\text { keuangan }\end{array}$ & $\begin{array}{l}\text { BNI hanya mengungkapkan ketentuan yang digunakan untuk } \\
\text { melakukan saling hapus, tanpa mengungkapkan lebih lanjut } \\
\text { mengenai aset dan liabilitas apa yang disalinghapuskan dan } \\
\text { jumlah- jumlah yang terkait dengan saling hapus }\end{array}$ & Tidak Sesuai \\
\hline Agunan & $\begin{array}{l}\text { BNI mengungkapkan dalam Liabilitas lain-lainnya setoran } \\
\text { jaminan yang diberikan untuk penjaminan atas kredit dan } \\
\text { fasilitas perbankan lainnya }\end{array}$ & Sesuai \\
\hline $\begin{array}{l}\text { Akun penyisihan } \\
\text { kerugian kredit }\end{array}$ & $\begin{array}{l}\text { BNI mempunyai akun cadangan kerugian penurunan nilai } \\
\text { sehingga penurunan nilai tidak langsung mengurangi nilai } \\
\text { tercatat aset keuangan yang rekonsiliasinya diungkapkan } \\
\text { dalam catatan atas laporan keuangan }\end{array}$ & Sesuai \\
\hline $\begin{array}{lr}\text { Instrument } & \text { keuangan } \\
\text { majemuk dengan } \\
\text { derivatif melekat }\end{array}$ & $\begin{array}{l}\text { BNI mengungkapkan dalam efek yang diterbitkan mereka } \\
\text { bahwa BNI hanya menerbitkan obligasi yang diterbitkan } \\
\text { melalui BNI cabang London. }\end{array}$ & Sesuai \\
\hline Gagal Bayar & $\begin{array}{l}\text { BNI tidak mengungkapkan gagal bayar dalam pinjaman yang } \\
\text { diterimanya }\end{array}$ & Tidak Sesuai \\
\hline
\end{tabular}

Sumber: Data olahan, 2016

Tabel 2. Perbandingan Pengungkapan Aset Keuangan berdasarkan PSAK 60 dengan PT BNI Tbk pada Laporan Laba-Rugi dan Pendapatan Komprehensif Lain PT. BNI, Tbk

\begin{tabular}{|l|l|l|}
\hline Berdasarkan PSAK 60 & \multicolumn{1}{|c|}{ Berdasarkan Bank BNI } & Keterangan \\
\hline $\begin{array}{l}\text { Pos-pos penghasilan, } \\
\text { beban, keuntungan atau } \\
\text { kerugian }\end{array}$ & $\begin{array}{l}\text { Dalam laporan laba rugi dan pendapatan komprehensif lain BNI, } \\
\text { BNI mengungkapkan keuntungan atau kerugian neto atas aset } \\
\text { keuangan dan liabilitas keuangan, beban dan penghasilan bunga, } \\
\text { penghasilan dan beban imbalan dan jumlah kerugian penurunan } \\
\text { nilai }\end{array}$ & Sesuai \\
\hline
\end{tabular}

Sumber: data olahan, 2016 
Tabel 3. Perbandingan Pengungkapan Aset Keuangan berdasarkan PSAK 60 dengan PT BNI Tbk pada Pengungkapan Lainnya PT. BNI, Tbk

\begin{tabular}{|l|l|l|}
\hline Berdasarkan PSAK 60 & \multicolumn{1}{|c|}{ Bedasarkan Bank BNI } & Keterangan \\
\hline Kebijakan Akuntansi & $\begin{array}{l}\text { BNI mengungkapkan dasar pengukuran untuk pengukuran awal, } \\
\text { pengukuran setelah pengukuran awal dan penghentian pengakuan } \\
\text { untuk aset keuangan juga kebijakan lain yang terkait. }\end{array}$ & Sesuai \\
\hline Lindung nilai & $\begin{array}{l}\text { BNI mengungkapkan deskripsi mengenai lindung nilai, instrument } \\
\text { yang digunakan untuk lindung nilai adalah interest rate swap yang } \\
\text { digunakan untuk lindung nilai terhadap risiko suku bunga }\end{array}$ & Sesuai \\
\hline Nilai Wajar & $\begin{array}{l}\text { BNI mengungkapkan nilai wajar yang dibandingkan dengan nilai } \\
\text { tercatatnya pada setiap kelas aset keuangan }\end{array}$ & Sesuai \\
\hline
\end{tabular}

Sumber: data olahan, 2016

Tabel 4. Perbandingan Pengungkapan Aset Keuangan berdasarkan PSAK 60 dengan PT BNI Tbk pada Pengungkapan Risiko PT. BNI, Tbk

\begin{tabular}{|l|l|l|}
\hline Berdasarkan PSAK 60 & \multicolumn{1}{|c|}{ Bedasarkan Bank BNI } & Keterangan \\
\hline Pengungkapan kualitatif & $\begin{array}{l}|c| \\
\text { BNI telah mengungkapkan dalam Catatan atas laporan } \\
\text { keungannya mengenai eksposur tiap risiko, bagaimana risiko itu } \\
\text { timbul, tujuan, kebijakan dan proses pengelolaan risiko dan } \\
\text { metode pengukuran risiko. }\end{array}$ & Sesuai \\
\hline $\begin{array}{l}\text { Pengungkapan } \\
\text { kuantitatif }\end{array}$ & $\begin{array}{l}\text { BNI mengungkapkan data-data kuantitatif yang terkait dengan } \\
\text { risiko, baik itu risiko kredit, risiko likuiditas maupun risiko pasar. }\end{array}$ & Sesuai \\
\hline
\end{tabular}

Sumber: Data Olahan, 2016

\section{Pembahasan}

Pengungkapan Informasi Aset Keuangan PT. Bank Negara Indonesia (persero) Tbk sebagian besar telah sesuai dengan persyaratan dalam PSAK 60 revisi 2014. Pada Pengungkapan Aset Keuangan terkait Laporan Posisi Keuangan PT. Bank Negara Indonesia (persero) Tbk poin-poin seperti kategori Aset keuangan, aset keuangan yang diukur pada nilai wajar melalui laba rugi, reklasifikasi, agunan, akun penyisihan kerugian kredit, instrument keuangan majemuk dan derivatif melekat telah diungkapkan sesuai dengan PSAK 60, sementara poin mengenai gagal bayar dan saling hapus aset keuangan dan liabilitas keuangan masih belum sesuai dengan PSAK 60. Pada pengungkapan aset keuangan terkait dengan Laporan Laba Rugi pos-pos penghasilan, beban, keuntungan atau kerugian telah diungkapkan sesuai dengan PSAK 60. Pada pengungkapan aset keuangan terlait pengungkapan lainnya, kebijakan akuntansi perusahaan, nilai wajar dan akuntansi lindung nilai perusahaan telah sesuai dengan PSAK 60. Pada pengungkapan aset keuangan perusahaan terkait dengan pengungkapan risiko, pengungkapan kualitatif maupun pengungkapan kuantitatif BNI telah sesuai dengan PSAK 60.

\section{Kesimpulan}

\section{PENUTUP}

Kesimpulan dari penelitian ini adalah pengungkapan atas aset keuangan PT. Bank Negara Indonesia (persero) Tbk sebagian besar telah sesuai dengan PSAK 60 Instrumen Keuangan: Pengungkapan. Meskipun begitu masih ada beberapa poin yang belum sesuai pengungkapannya dengan PSAK 60 seperti dalam pengungkapan gagal bayar dan pelanggaran serta pengungkapan tentang saling hapus aset keuangan dan liabilitas keuangan.

\section{Saran}

Saran dari penelitian ini adalah Sebagai BUMN dan juga perusahaan yang sudah go public, BNI sepatutnya mengikuti persyaratan PSAK 60 untuk pengungkapan keuangannya. Penulis menyarankan agar perusahaan tetap mempertahankan kesesuaian pengungkapan aset keuangannya 
dengan PSAK 60 dan menambahkan pengungkapan tentang gagal bayar dan pelanggaran dan pengungkapan tentang jumlah-jumlah yang terkait dengan saling hapus aset keuangan dan liabilitas keuangan serta terus mengikuti perkembangan perubahan standar akuntansi keuangan dan menerapkannya pada laporan keuangan perusahaan.

\section{DAFTAR PUSTAKA}

Bonetti, Pietro, Marco Maria Mattei, Fabrizio Palmucci, 2012. "Market Reaction To the Disclosures On Currency Risk Under IFRS 7". Academy of Accounting and Financial Studies Journal ISSN: $\quad 1528-2635 \quad$ Volume $16, \quad 3$. http://www.alliedacademies.org/articles/aafsjvol1632012.pdf. diakses 4 Februari 2016. diakses 4 Februari 2016.

Cernohorska, Libena, 2015. "Impact of Financial Crisis on the Stability Banking Sectors in the Czech Republic and Great Britain”. Procedia Economics and Finance 26 ( 2015 ) $234-241$. Http://www.elsevier.com/locate/procedia. diakses tanggal 11 Maret 2016.

Emanuela, 2012. Analisis Penerapan PSAK 50 dan 55 (Revisi 2006) atas Impairment Piutang pada Perusahaan Multifinance. Universitas Indonesia. http://lib.ui.ac.id/file?file=digital/20311187S42786-Analisis\%20penerapan.pdf. Diakses pada 3 Februari 2016

Ikatan Akuntan Indonesia, 2015. Standar Akuntansi Keuangan. Cetakan pertama. Dewan Standar Akuntansi Keuangan Ikatan Akuntansi Indonesia, Jakarta.

Kasmir, 2012. Dasar-dasar Perbankan. Edisi revisi. RajaGrafindo Persada. Jakarta.

Lam, Nelson, Peter Lau, 2012. Intermediate Financial Reporting. Second Edition. Salemba Empat. Jakarta.

Larasati, Agustina dan Supatmi, 2014. "Pengungkapan Informasi aset keuangan dan Impairment-nya Di Perbankan menurut PSAK 50 dan 60". Publikasi Ilmiah UMS.Fakultas Ekonomika dan Bisnis, UKSW salatiga. ISBN: 978-602-70429-1-9 http://publikasiilmiah.ums.ac.id/handle/123456789/4650. Diakses pada 20 September 2014. Hal 296-309.

Longgorung, Lisa Christy, 2015. Pengungkapan Informasi Aset Keuangan Menurut PSAK 60. Universitas Sam Ratulangi Manado. Jurnal EMBA ISSN: 2303-1174 Vol.3 No.1 Maret 2015. http://ejournal.unsrat.ac.id/index.php/emba/article/view/7244. Diakses 22 September 2015. Hal 524-533.

Muthupandian, K S, 2012. "IFRS 7 Financial Instruments: Disclosures - A Closer Look". Munich Personal RePEc Archive Paper. https://mpra.ub.uni-muenchen.de/36723. diakses 4 Februari $\underline{2016}$

Pontoh, Winston, 2013. Akuntansi Konsep dan Aplikasi. Halaman Moeka. Jakarta.

Supriyono, Maryanto, 2011. Buku pintar Perbankan. Edisi Pertama. ANDI. Yogyakarta.

Sugiyono, 2012. Metode Penelitian Kuantitatif dan Kualitatif (R\&D). Cetakan ke 19. Alfabeta. Bandung 